$$
\begin{aligned}
& 1.3 \times 9 \quad \text { onme-5006 } \\
& \text { MASTR }
\end{aligned}
$$

\title{
Use of Instrumented Charpy Tests to Determine Onset of Upper-Shelf Energy
}

\author{
D. A. Canonico \\ W. J. Stelzman \\ R. G. Berggrer: \\ R. K. Nanstzd
}

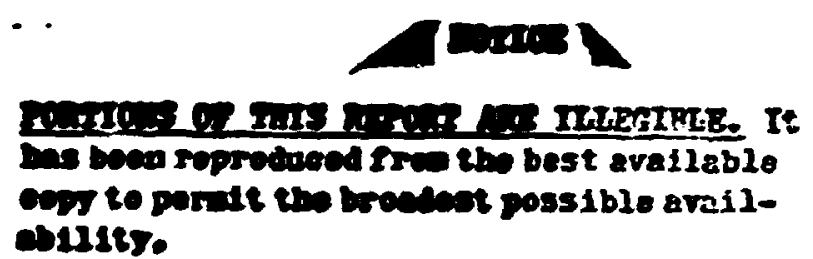




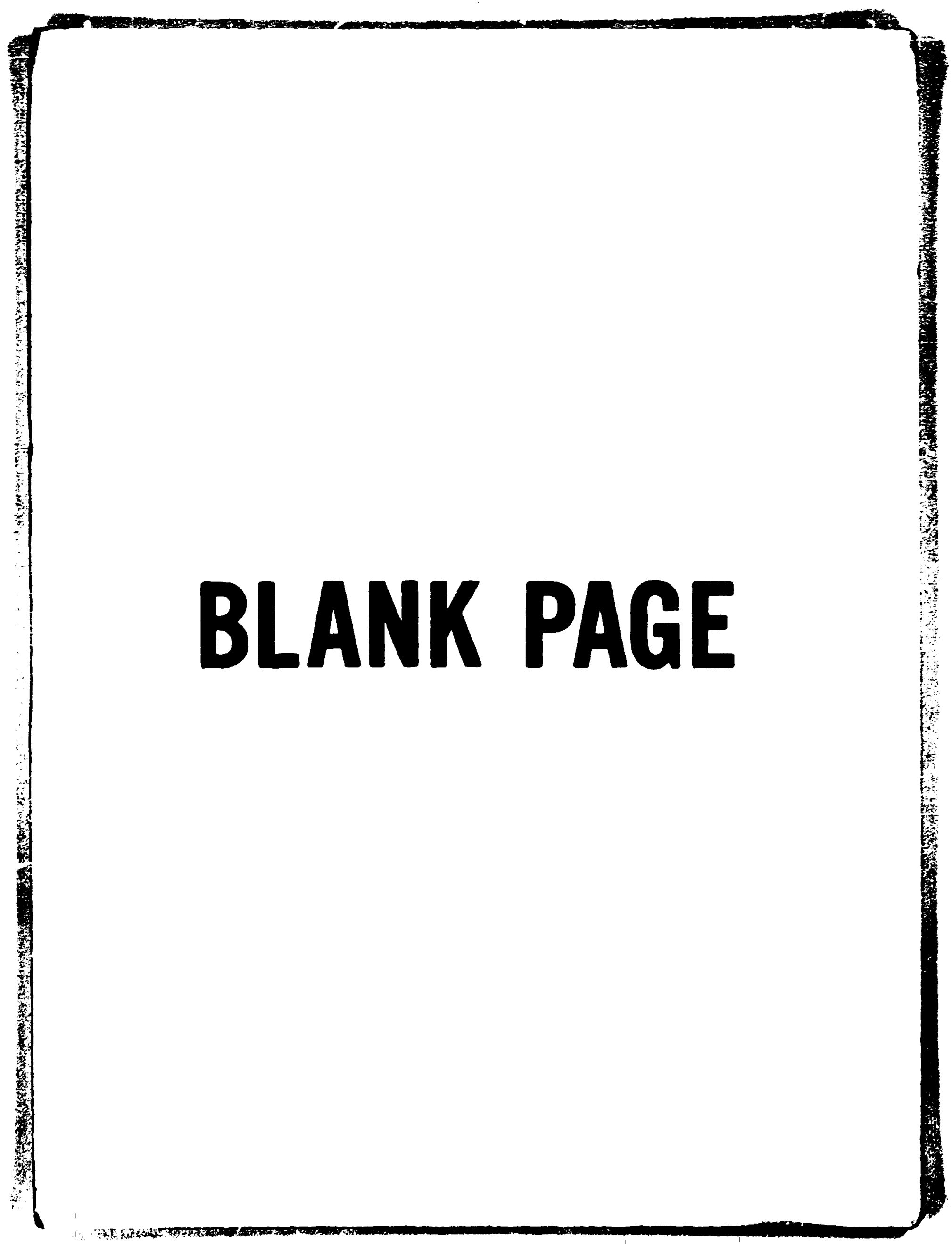




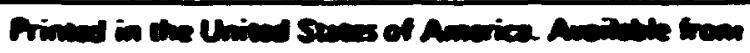

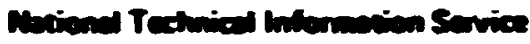

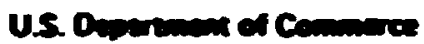

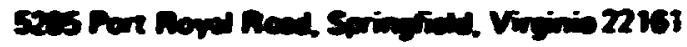

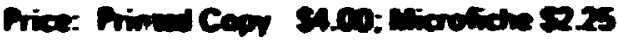

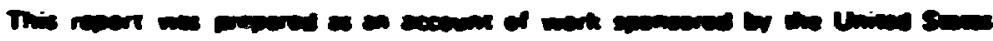

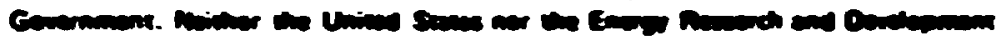

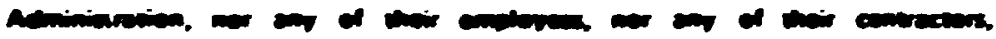

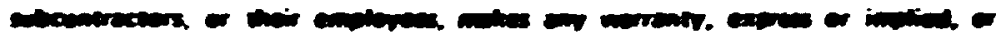

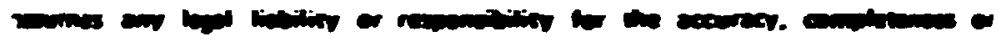

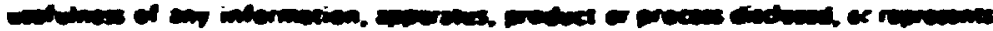

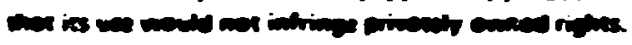


Contract No. W-7405-eng-26

MLTALS ND CERAYICS DIVISIOX

USE OF IRSTRUMEXTED CHARPY TESTS TO DET SRMIXE ONSET OF UPPER-SHELF ENERCY

D. A. Canokico, U. J. Stelzan, R. C. Bergeren, and R. K. Kanstad

OAK RIDCE MATIONAL LABORATORY

Oak Ridge, Tennessee 37830 operaced by URION CARBIDE CORPORATION for the

U.S. ENERGY RESEARCH AND DEVELOPMENT AOMINISTRATION 
comrars

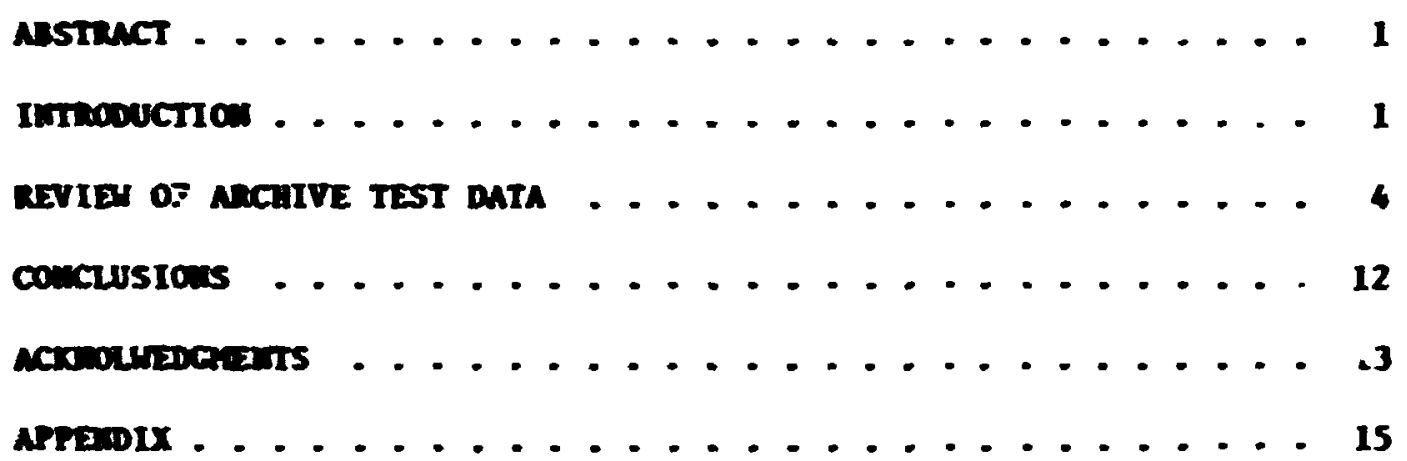


USE OF IXSTMUTITED CANRY TESTS TO

D. A. Canonico, U. J. Stelenan, R. G. Eeresrea, and R. R. Lenstad

\begin{abstract}
AnSTINT
The definition of the Charpy V-wotch (C, ) upper-shelf eneres is an elusive target. Fost resiearcbers define the upper shelf as that temperature range in wich the surface of the $C$ paecinen exhibits a appearance indicative of a $100 \mathrm{~m}$ ductile fracture. The deternination of the percent ductile fracture in a tested C specinen depends upon incerpretation ad can verg froe individuhl to individual. We have sought to aroid the nood for incerpretation and have elected to base the selection of the C uprex-shelf mergy on the results frcm an iastruneated inpect test. The instrumed inpact test provides a pernoment record of the lan-deflection history of a $C_{\text {y }}$ spectinen durias the cesting sequence. In the transition tenprature reste (ubere the wode of failute chanaes fros britcle at lou tempratures to ductile at high tempratures) a precipitous drop in the load trace occurs. The ande of the drep decreases at higher temperatures until it is zero. The zero-dropin-load teaperature is identical to the onset of the 6 upper shelf. This relationship between the drop in load ad energy in an instruneated ispact test provides incontestable sesourance that the C upper sheif has been obtaibed. This relationship between drop in losd and temperature pernits a predfetion of the coret of the unershelf temperature vith as few as two instrunented inpact tests.

We have also shown that the ail-ductility temperature (Dr) (deternined by the drop-weight test) is related to the Cy upper shelf. Por the SA-503 Clase 2 and SA-533 Grade B Clase 1 steels "aployed in the fabrication of prescure vessels for light-water resctors $C_{\text {v }}$ testins at wI $+180^{\circ} \mathrm{F}\left(100^{\circ} \mathrm{C}\right)$ wlll provide upper-shelf ewerey values.
\end{abstract}

\title{
Irmooverion
}

Two steels are curreatly being eployed in the fabrication of the preseure vesecls for muclear reactors - the SA-533 Grade 8 Clase 1 and SA-50s Class 2 steels. Table 1 contains the chenfeal aalyols and afnima extrancal property requitenents for these steels. These pressure-ressel steels are eabriteled as a consequence of an exposute to irradiation. The degree of enbrittlement depends on the residual alements, specifically copper and phosphorus, which are usually found in comercial heats of these steels. This embrittlement is reflected b; a shange in the 
Table 1. Material Specificatioas for Pressure Vessel Steels

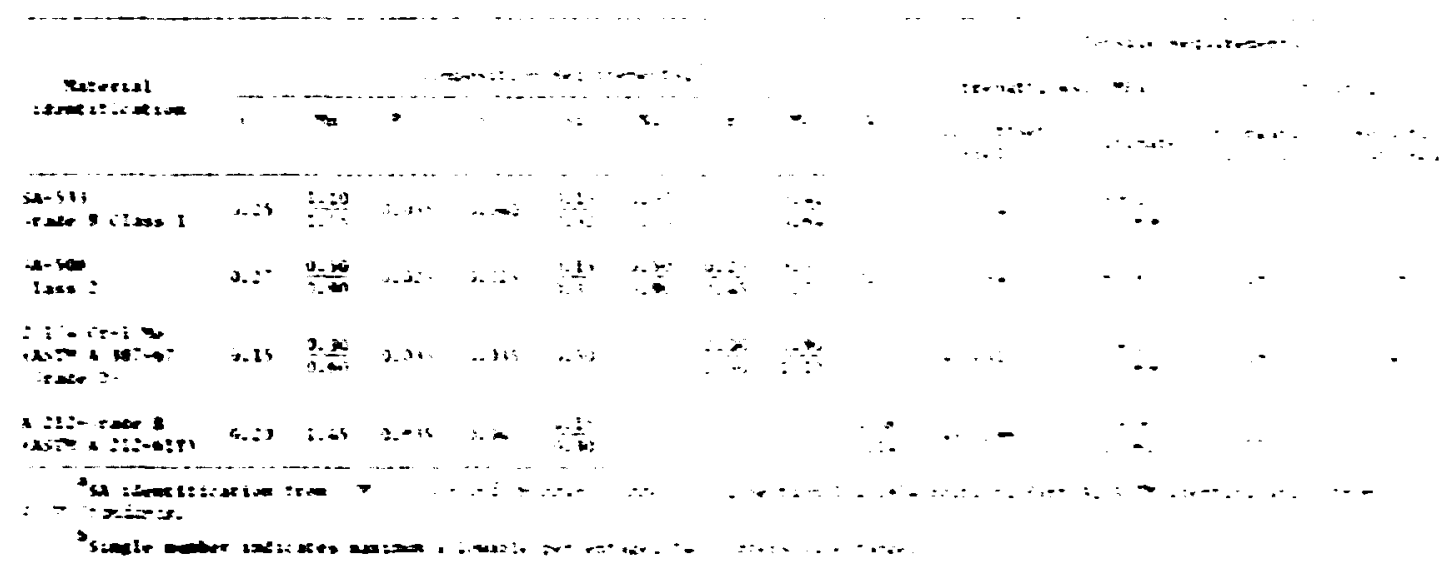

cougbaess and strength properties. Survefllance prograns exployer in the nuclear industry are designed to predict the property changes that occur in the steels aployed in the fabrication of a muclear pressure vessel, and chase changes are considered in the operation of an emergy systen.

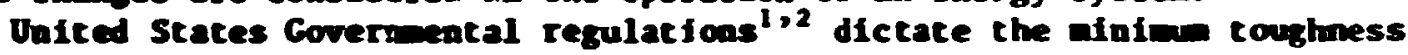
requirenents for these steels when they are initially put into service and during their serviceable lifetine. The Federal Register describes the Dinim allowble Charpy $v$-wotch $\left(C_{v}\right)$ upper-shelf energy of the steels aployed in the fabrication of presture vessels for nuclear applications. The Rules and Regulations state "the Charpy V-notch upper-shelf energy repeiremencs for beltilice resion materisls was set at 75 ft-1b for all cases without distinction as to the predfited mount of irradiation danage." These references sursest a standard definition of "upper-shelf" energy; houver, auch an explicit definition does not exist. In the absence of a standard definition, the suclear Rezulatory Comission (inc) has def ined ${ }^{2}$ the upper shelf ". . as the average esersy value for all specinens whose cest cemperature is above the upper end of the transition tenperature region. Dormally, at least three specinene should be included; nore specimens should be included when the shelf level appears to be arginal." acsurance that the tests have indeed been conducted in the upper shelf is not guaranteed by this test procedure. The deternimation of the upper end of the craasition temperature is not alwajs self-evident. The uppershelf behavior of various grades of steel is not consistent. The energy naj increase, decrease, or remain constant. An example of each mode of

'Ped. Regist., 38(136): 19013 (July 17, 1973), Washington, D.C.

${ }^{2}$ U.S. Muclrar Regulatory Consission, Regulatory Guide 1.99, EjJects of Residual Elements on Predicted Radiation Dange to Reactor Vessel Materiale, Tentative. 
behovior is show' in Fis. I. The Charpy V-aotel (C.) dace presented in Fig. I are from the sace steel plate (plate 01) tahed froe three locations

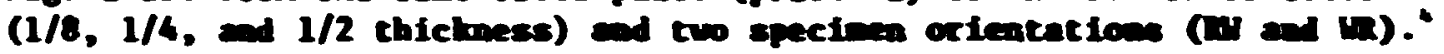
This plate satisfies the Code repuirenents for SA-533 Grade B Class 1 steel.

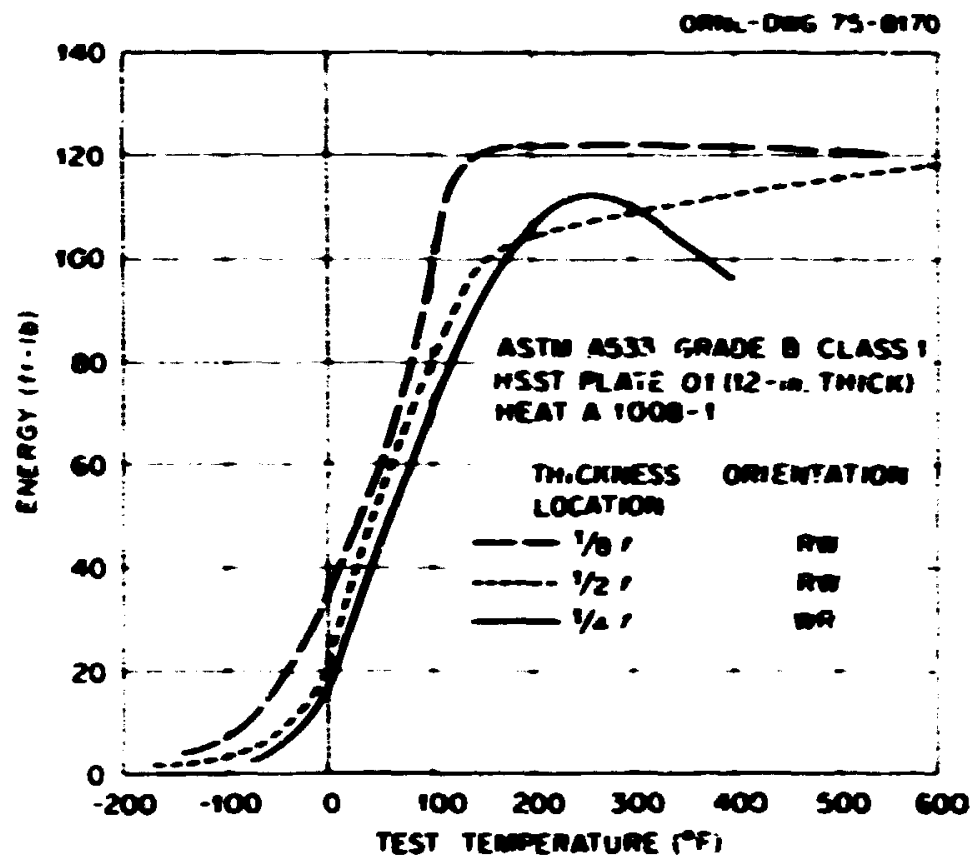

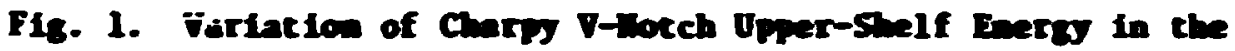
Sam Plate of SA-533 Grade B Clase 1 steel.

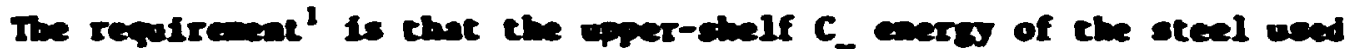
in the beltifine resion of a melear preware veleel be at least $75 \mathrm{ft}-1 \mathrm{~b}$ $(102 \mathrm{~J})$. To deternite how a repatable oreatization easures itself that

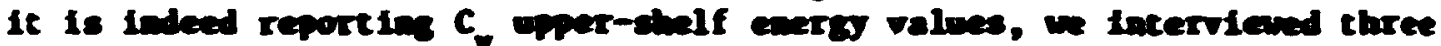
experincaters who are refreventative of the leading eqperts is this area of nechanical propetty teating. We ppecifically acked then to describe their eethod for acouring thaselives thet they are indeed report-

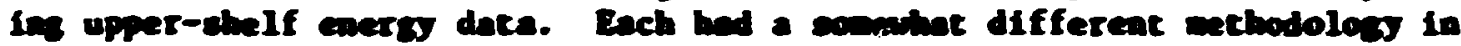

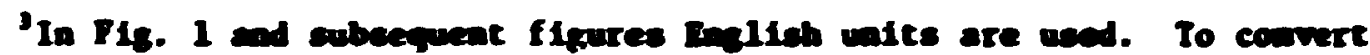
to SI: Multiply energy values in foot-pouds by 1.3530 to get joulee;

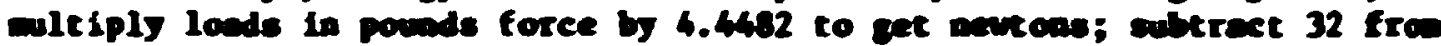
Fabreabieit temperatures, then witiply by $5 / 9$ to pet Calsius dexces.

the firat letter describes the axis of che spectinen. The secoud letter describes the fracture poth. $R$ is rolline direction; $W$ is traes verce to the rolling direction. 
his testing progra, but all depended on fracture appearamie as their cricerion. Their requirenents are that the fracture surfaces of the $C_{v}$ specimens exhibit an afpearance indi-ative oi nearly $100 \%$ shear iracture. A brief description of the netbod described by each experimenter intervieved is provided in the Appendix. The use of fracture appearance as a criterion depends on individual interpretation of the fracture surface. The probability for differences of opinion in the interpretition of the surface is great.

In view of the possible variations in $C_{y}$ upper-shelf behavior shown in Fig. 1, (1.e., Increasiag energy with licrease in temperature, decreasing exergy with iecrease in cemperature) and the huan cacertainty involved in the interpretation of a fracture surface, the authors have deternined an ieproved ectood for describing the $C$ upper-shelf energy value of the steels eiployed in the fabrication of the nuclear pressure vessels used for Light Water Reactors (LIR). Saxc is desirous of a standard nethod for assessing the effect of irradiation on the fracture coughness of the Lin pressure vessels. Its interest iles in the development of a definition of the $c_{v}$ upper she! $f$ based on a reproducible tes: procedure that is acceptable to the industrial commaty. It recognizes that the nuber of irradiated specineas is often linited, and a precise and repeatab:e method is desired for describing the $C_{y}$ upper shelf. The autho-s feel that the sethod described in this report may sat isfy the kRC needs.

RETIEN OF ARGIVE TEST DATA

To avoid vegueness or atsincerpretation in the selection of an uppershelf energy value, we sought a definitior based no a specific criterion that could be readily obtafned in a convent fotal toughness test. Toward that end ve revieved the $C_{\text {data }}$ that have been obtained in the Heavy Section Steel Technology Flogran (ISST) test series and ocher Energy Research aod bevelopment Adainistration (EMA) prograns. The $C_{\mathrm{v}}$ cests were run on instrunented Ralduin inpact tester, Model S11C. The tester shown in Fis. 2 autconcically cools (or heats) the $C_{y}$ specinea and woves it into position for testing. The striker that cobtacts the specinen is inatrumented with strajn gages, and a lad-tine curve can be obtained for each teat. This capobility was (and is) utilized during $C_{y}$ ". -ing. The cbllity to generace a land-tine curve for che $C$ test prooldes a permoweat record of a cest ser ies. Eence, in addicion co the absorbed eserey (read from the achise dial), lateral expanion (a post-test weasurewent), and frecture appearence (est fanted persent ductile iracture), a permaseat record (Polarold canera print or $x-y$ plot) of the land-time curve is obratined for each cest.

the have reviewed the loab-tine curves for the state-of-the-art auclear preacure veacel stcels, as wil a other plafn carbon (ASH A 212 Grade B) and low-allog $(21 / 4 \mathrm{Cr}-1 \mathrm{no})$ sceels. The chenteal compositioss of these later two steels are given in Table 1. In reviewing the loed-tine records for tbese steels we found that in all the tests mactable crack extenaion that 1s, pop-in - occurs in the transielon temerature regine. This crack extenstion is reflected as a drop in load in the load-tine curves and is an easily deterniond quantity. The drop-in-losd value (AP) decteases 


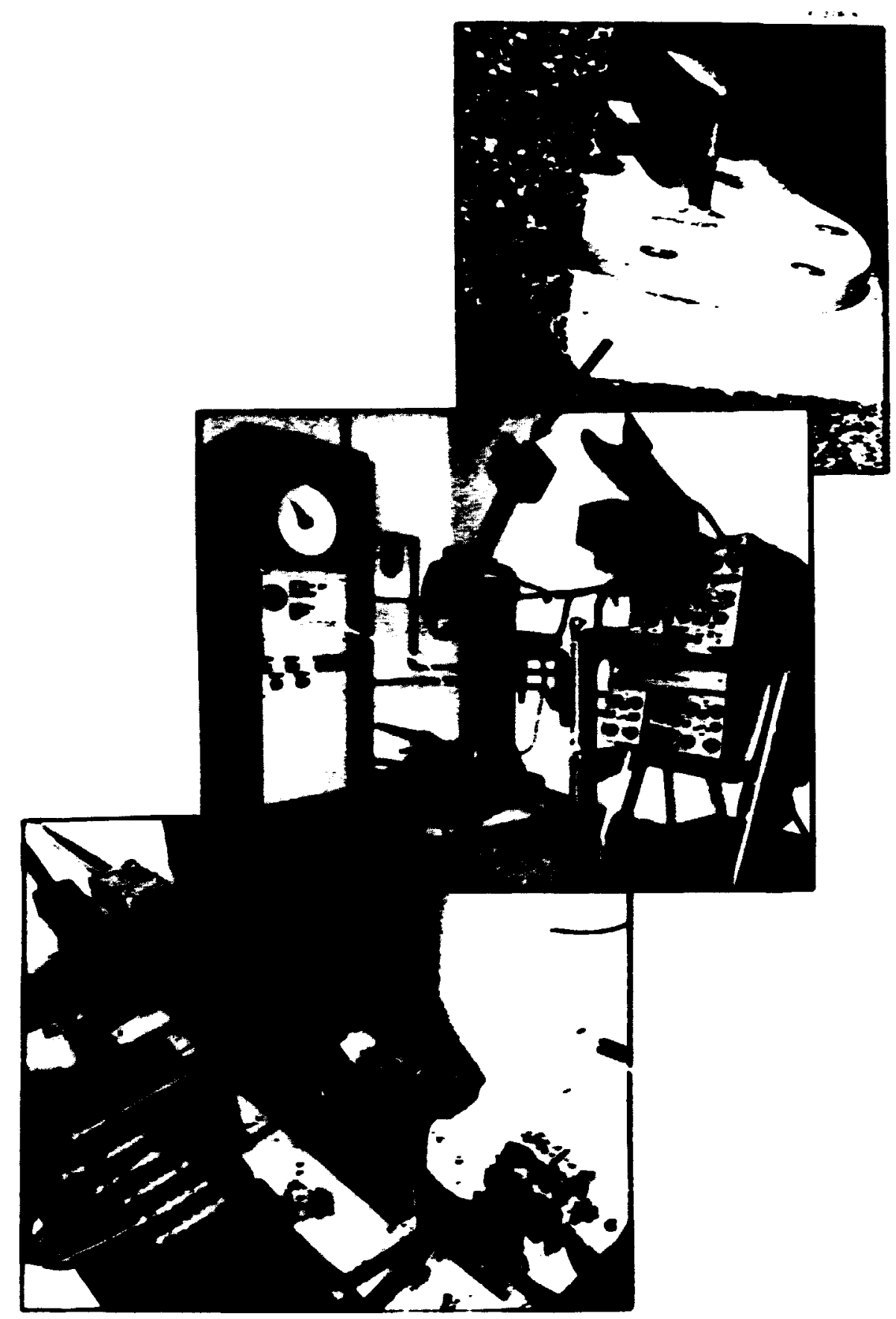

Fig. 2. Instrunewted Impact Tester. Center photograph shours the eatire system: impact tester, cemperature-measur ing equipment, electronic equipment for measurias and recording lnad and deflection. Upper right photograph is close-up view of strain-gaged tup. Lower left corner is view of automated Charpy specimen cooling (and heating) and loading apparatus. 
with increasing teperature in the trinsition range, approaching zero at the temperature of the conset of upper shelf in a $C_{y}$ test. This anterial behavior in a typical $C$, test is illustrated in Fig. 3. It contains cie results of a $C$ test on the impact tester shoun in Fis. 2. The Polaroid priats are representative of the data obtained when a $C$ test series is conducted on an instrumented impact tester. The definilion of the drof in laad, $\Delta P$, is providet in Fis. 2(b). A plain carbon steel, ASTM A 212 Grade B. has been used co desconstrate the variation in the load-tine curves as a function of temperature. The drop in load, $1 P$, in the $F$ vs : curve can be easily observed in (c) through (g) in Fig. 3. The if values vary fron a maxim value of $355016(15.6 \mathrm{~km})$ at $0^{\circ} \mathrm{F}\left(-18^{\circ} \mathrm{C}\right)$ to $800 \mathrm{lb}$ $(3.6 \mathrm{~kJ})$ at $80^{\circ} \mathrm{F}\left(27^{\circ} \mathrm{C}\right)$. At $100^{\circ} \mathrm{F}\left(38^{\circ} \mathrm{C}\right)$ the $\Delta^{\circ}$ is zero. The temperature at wich if equals zero :orresponds with the onset of the upper-stielf encrey in a $C_{y}$ test. This correlation is clearly seen in the graph in the center of Fig. 3.

$A$ review of the archire C data avallable for SA-503 Class 2 and SA-533 Grade Class 1 stee is lovestigated in the ESST Frogran provided sinilar correlations between $\triangle P$ and the onset of the upper shelf. The surves preseated in Fis. 4 are representative of che correlations between $\Delta P$ and $C$ meres noted in this regiew. The results for the ASTM A 212 Grade I Iteel illustraced in Fig. 3 are also included. Both the SA-533 and -503 stcels exhibit a decrease in the drop in load (pop-in) in the transition regie as a consequence of a temperature increase. The temperature at which AP tecones zero in both steels correspoods to the onset of upper shelf.

As a further check of the validity of this observation, we revieved the lasd-tine curves obtained fron tests of irradiated nuclear pressure vessel steels and coirrediated lon-carbon 2 1/4 $\mathrm{Cr}-1$ to steel. The $\mathrm{C}_{\mathrm{y}}$ curves and pop-in loads for a low-carbon 2 1/4 Cr-1 to s!eel are shown in Fifs. 5. This steel hed C energy values in excess of $240 \mathrm{ft}-1 \mathrm{~b}(330 \mathrm{~J})$

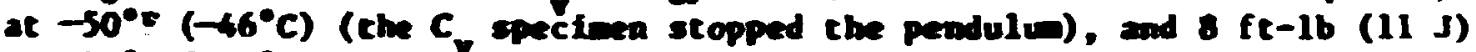
at $-75^{\circ} \mathrm{F}\left(-59^{\circ} \mathrm{C}\right)$. The correspond ing $\triangle P$ values are zero anc $3100 \mathrm{ib}$ $(13.8 \mathrm{~km}$ ). Aesia, the temperature at which ap becones zerc corresponds with the oaset of the upper shelf. This beat of steel would sot be used in the construction of a nuclear prescure vessel, but it does serve as an exaple of the applicability of the drop-in-load criterion for describing the onset of upper-shelf emeres.

Figure 6 contalies the results of tests conducted to deternise the effect of Irradiation on the $C$ properties of pressure vescel steels. The frradiated aterials provide results sinilar to thoce observed for the unirradiated steels; the temperature at wich the drop in load becones zero correspoads with the onsent of the upper shelf. The tenperature at wifch the oaset of upper shalf occurs in the untrrediated condition is influenced by the anisotropy of the steel. It is evident In Pig. 6 that the In orfentation echieves upper sheif at a teaperature approufacely $40^{\circ} \mathrm{P}\left(22^{\circ} \mathrm{C}\right)$ lower than does the $\mathrm{x}$ orientac fon. There $1 \mathrm{~s}$, however, a differeme of about $30 \mathrm{ft}-1 \mathrm{~b}(40 \mathrm{~J})$ betwen the two shelf values, tine wu having the higher energy. The onset of upper chelf after irrediation is not influenced by the origiaal plate anisotrops. The use of the drop-inloed correlation for definios the onset of upper shelf is particulariy ateractive when irrediated specinens are cested. The use of the $\Delta P$ criterfon uill minintze the nubber of speciens required to assure that uppershelf emerisy values have been obtained. 


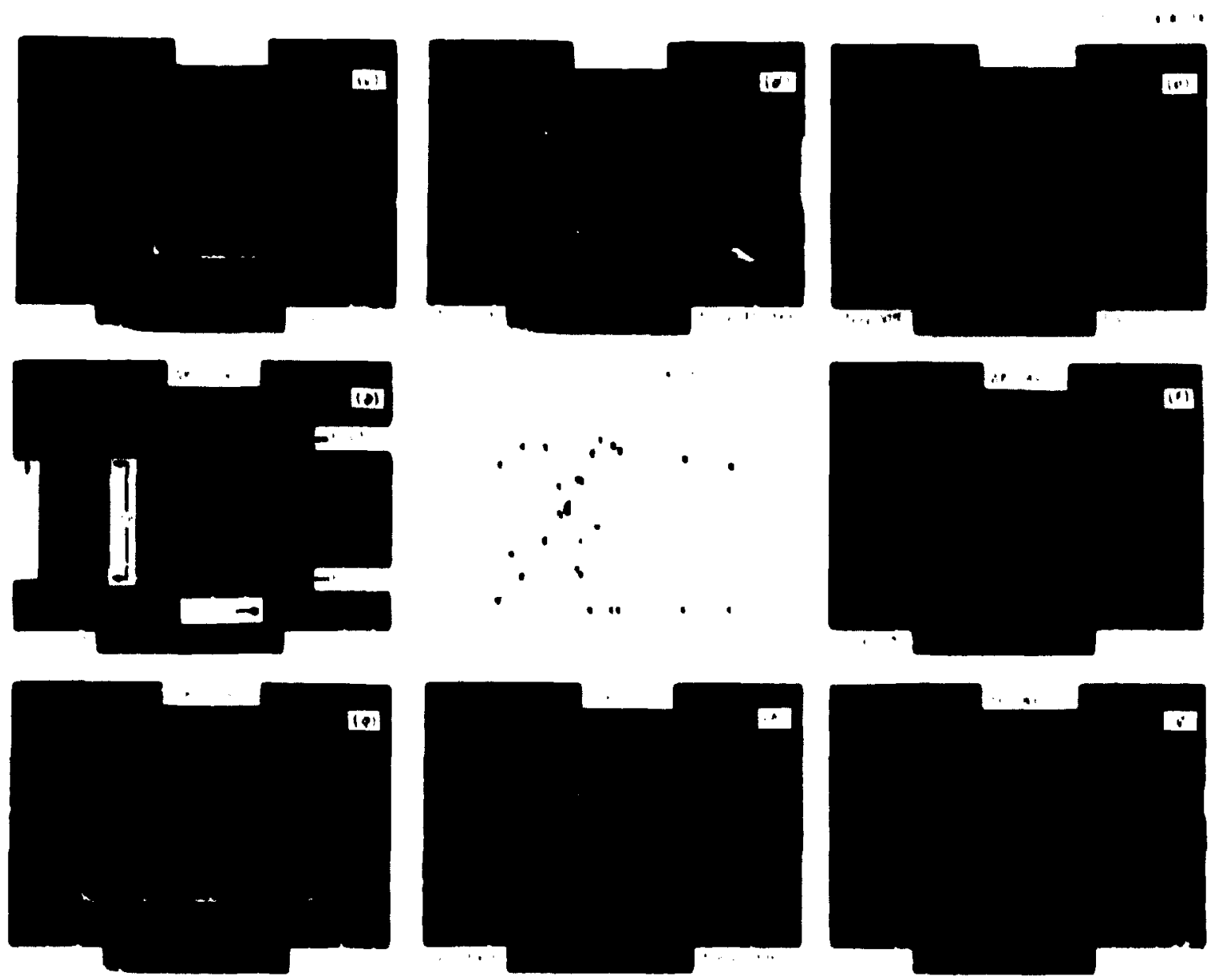

F18. 3. Compartuon of Inatrumented Charpy "Pop-1n" load Drop with Charpy-V Impact inergy for ASTM $\wedge 212$ lirade $B$ Sitelel. 

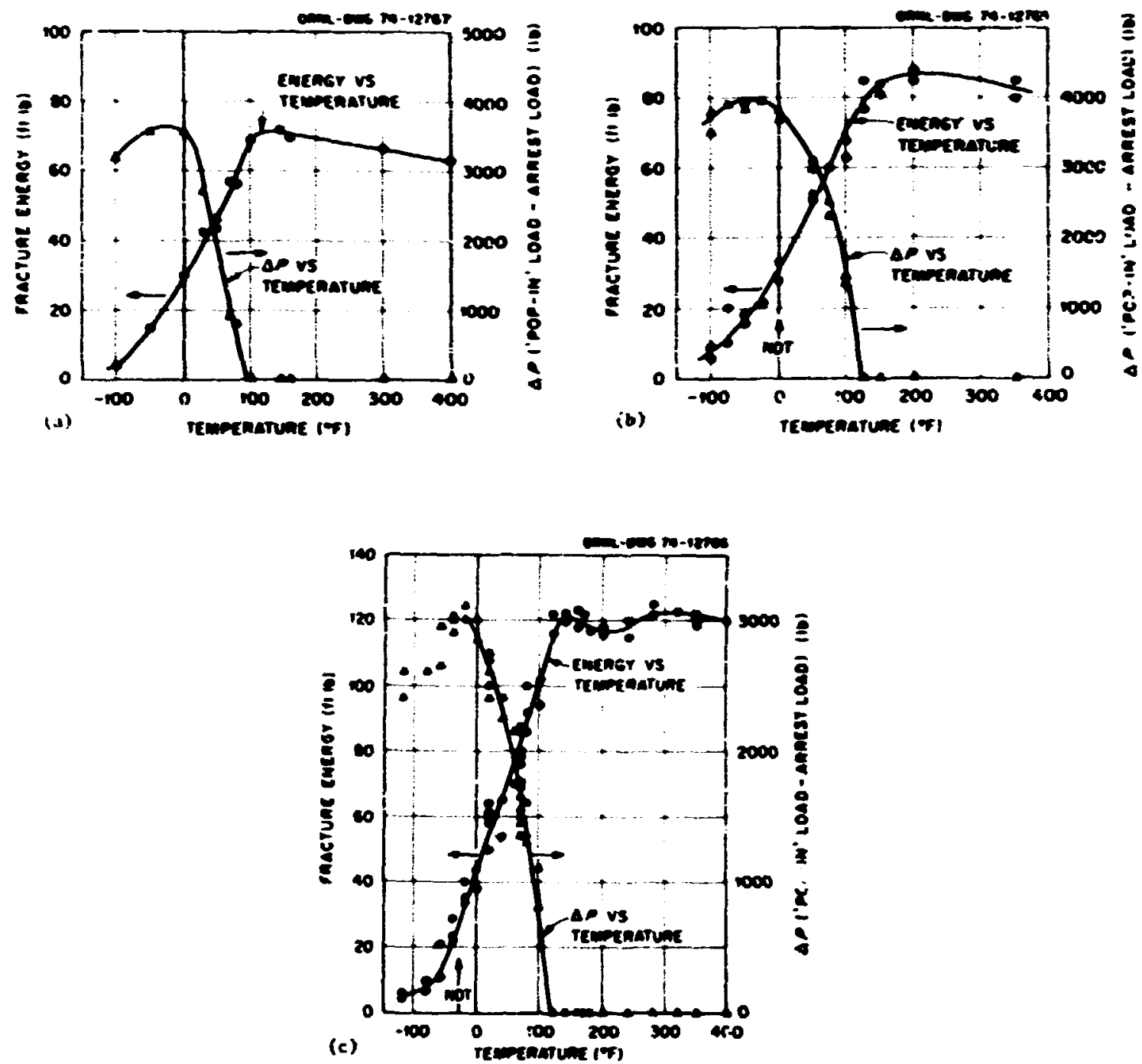

Fig. 4. Compartson of Instrumented Charpy "Pop-In" Load Drop with Charpy-V Impact Energy for Various Stee1s. (a) ASTM A 212 Grade B.
(b) SA-508 Class 2.
(c) SA-533 Grade B Class 1. 


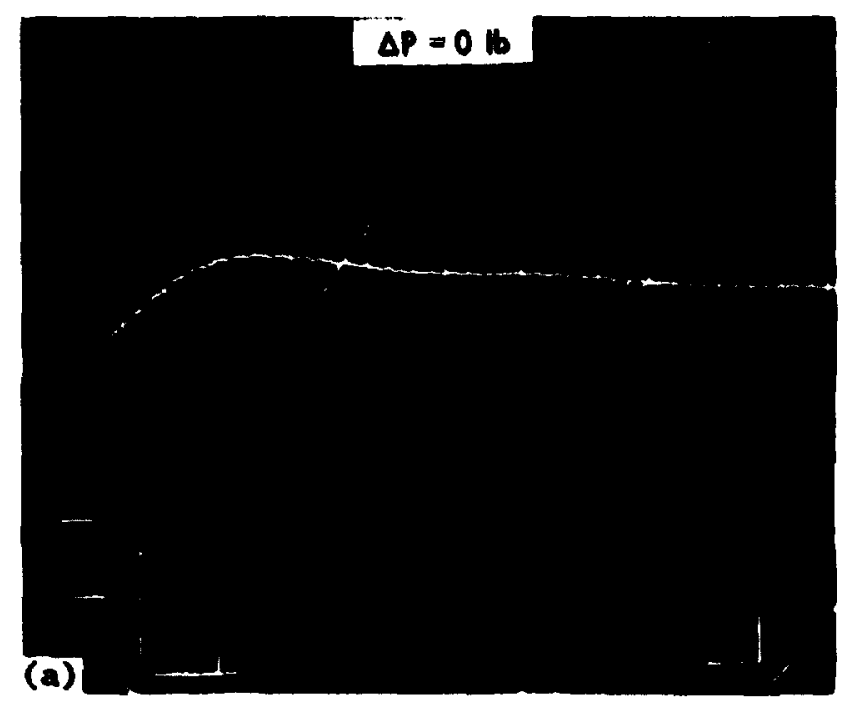

$x \cdot 12 \times 190$

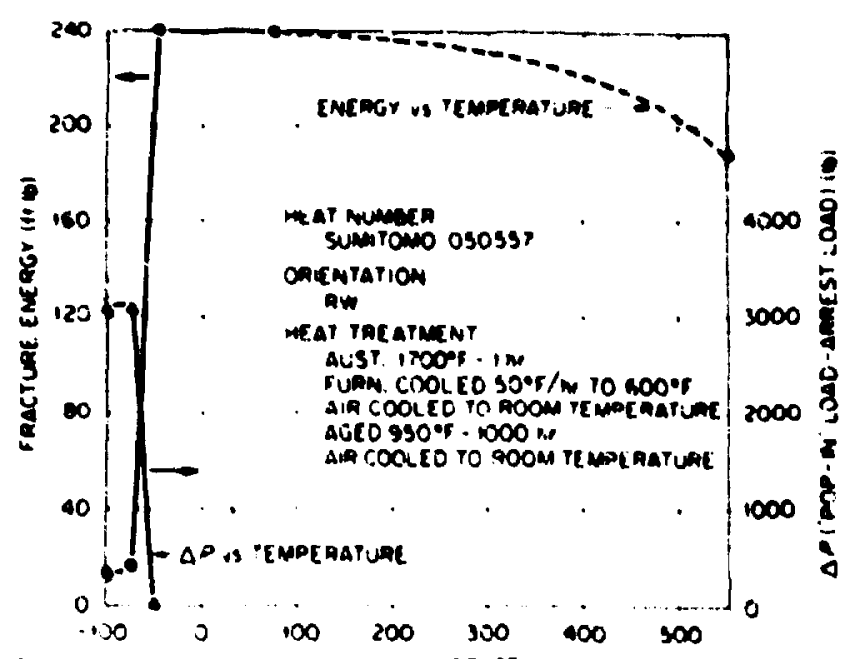

(c) iempeatuat: $: \%$,

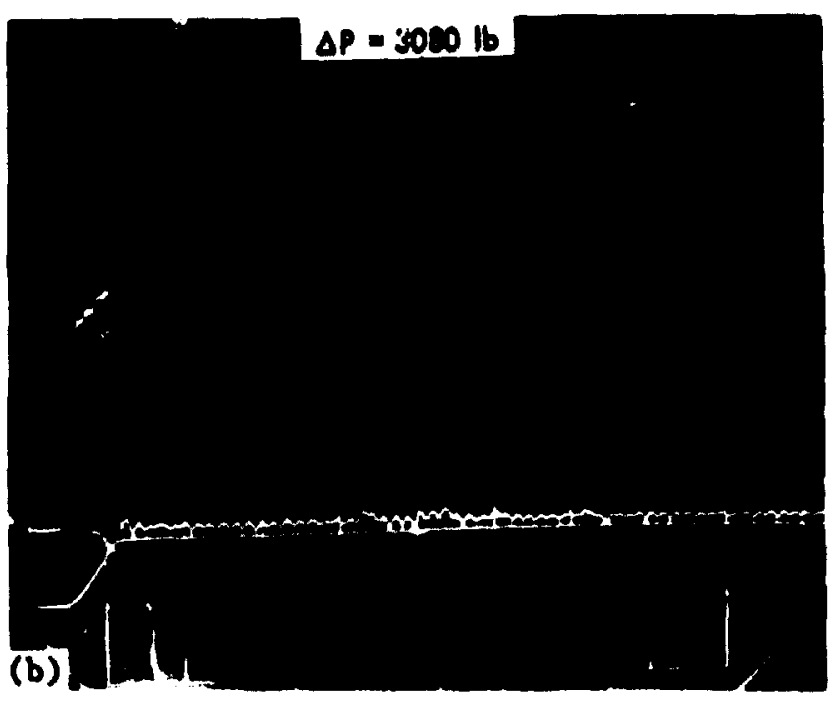

F18. 5. Comparison of Load Drop with Charpy-V Impact Energy in Instrumented Tenta of ASTM A 387 Grade $U$ (2 $1 / 4 \mathrm{cr}-1$ Mo with $0.026 \% \mathrm{C}$ ). (a) Test at $-50^{\circ} \mathrm{P}\left(-46^{\circ} \mathrm{C}\right)$, showing load drop $\Delta P=0$ and energy $240 \mathrm{ft}-1 \mathrm{~b}$ $(330 \mathrm{~J})$. (b) Teet at $-75^{\circ} \mathrm{P}\left(-59^{\circ} \mathrm{C}\right)$, showing load drop $\triangle P$ - $3080 \mathrm{lb}(13.70 \mathrm{kN})$ and energy $16 \mathrm{tt}-1 \mathrm{~b}(21 \mathrm{~J})$. (c) Fracture energy and load drop as function of temperature. 


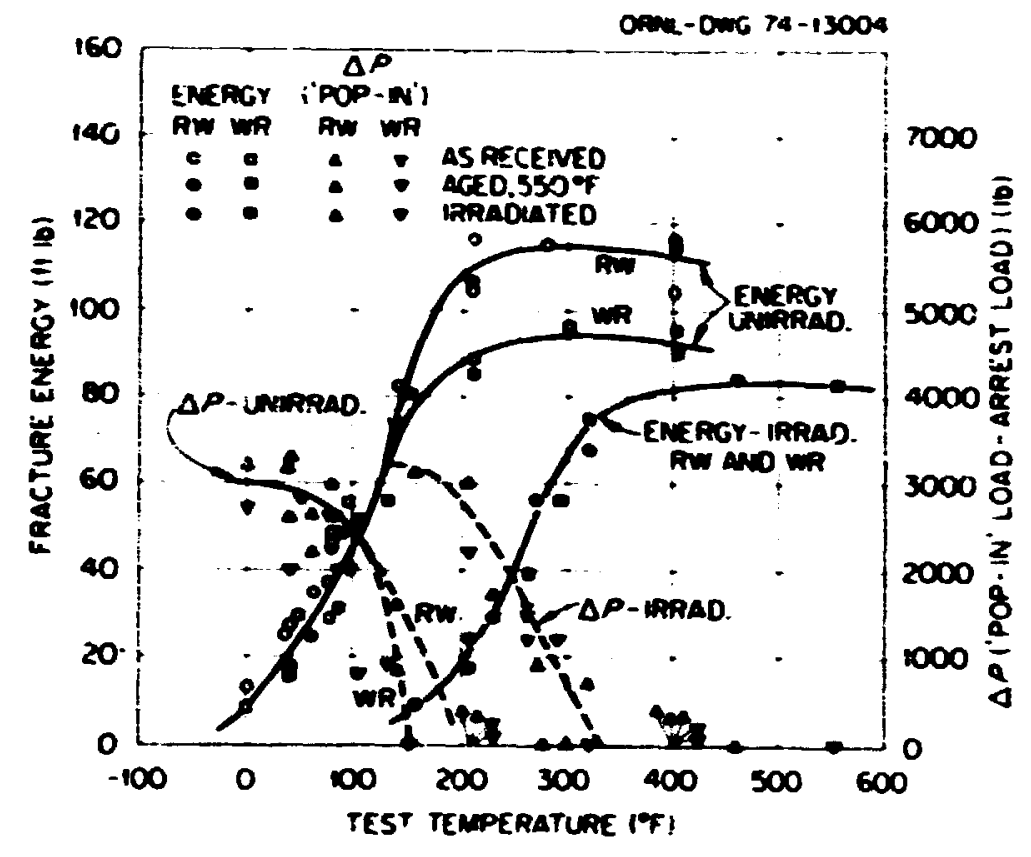

Fig. 6. "Pop-In" Load Drop and Charpy-V Impact Energy of SA-533 Grade B Class 1 Steel Quarter-Thickness Material, Unirradiated and Irradiated $\left(\approx 2 \times 10^{19} \mathrm{n} / \mathrm{cm}^{2},>1 \mathrm{MeV}\right)$.

The drop-in-load correlation provides an unambiguous criterion for defining the onset of $C_{y}$ upper-shelf energy. Such a criterion can be used by any organization with an instrumented impact tester that has the capability of obtaining a load-tine (or load-deflection) curve for individual tests. Ideally, the instrumented test systen is equipped to obtain a permanent copy of the load-time curve, and this information can becone part of the record on the individual nuclear plant.

Figure 7 compares fracture appearance, drop in load, and onset of the upper-shelf energy for the SA-533 and SA-508 spectiens used in the preparation of Fig. 5. The 1002 fibrous fracture appearance and the zero value for drop in load occur at the same temperature. Hence, the uppershelf energy values reported to date do indeed correlate with the data that would have been obtained using the drop-in-load criterion. The advantages of the zero-drop-in-load criterion, however, are: (1) the abilfty to quite precisely predict the zero- $\Delta P$ temperature when drop-in-1oad behavior is observed in a $C_{v}$ test, (2) the availability of an electronically generated permanent copy chat can be included in the record of a reactor plant, and (3) the avoidance of huan interpretation of a fracture surface and the If ulting possibility of differences of opinion.

In the absence of an instrumented inpact tester we would reconaend a correlation of the $C_{v}$ testing procedures with the nil-ductility temperature (NOT). Rather than depend on fracture appearance, we would prefer to relate the testing program of the unirradiated material to the NDT, a material property determination that is required for all steels employed in the fabrication of a nuclear pressure vessel. A relationship between NDT and 

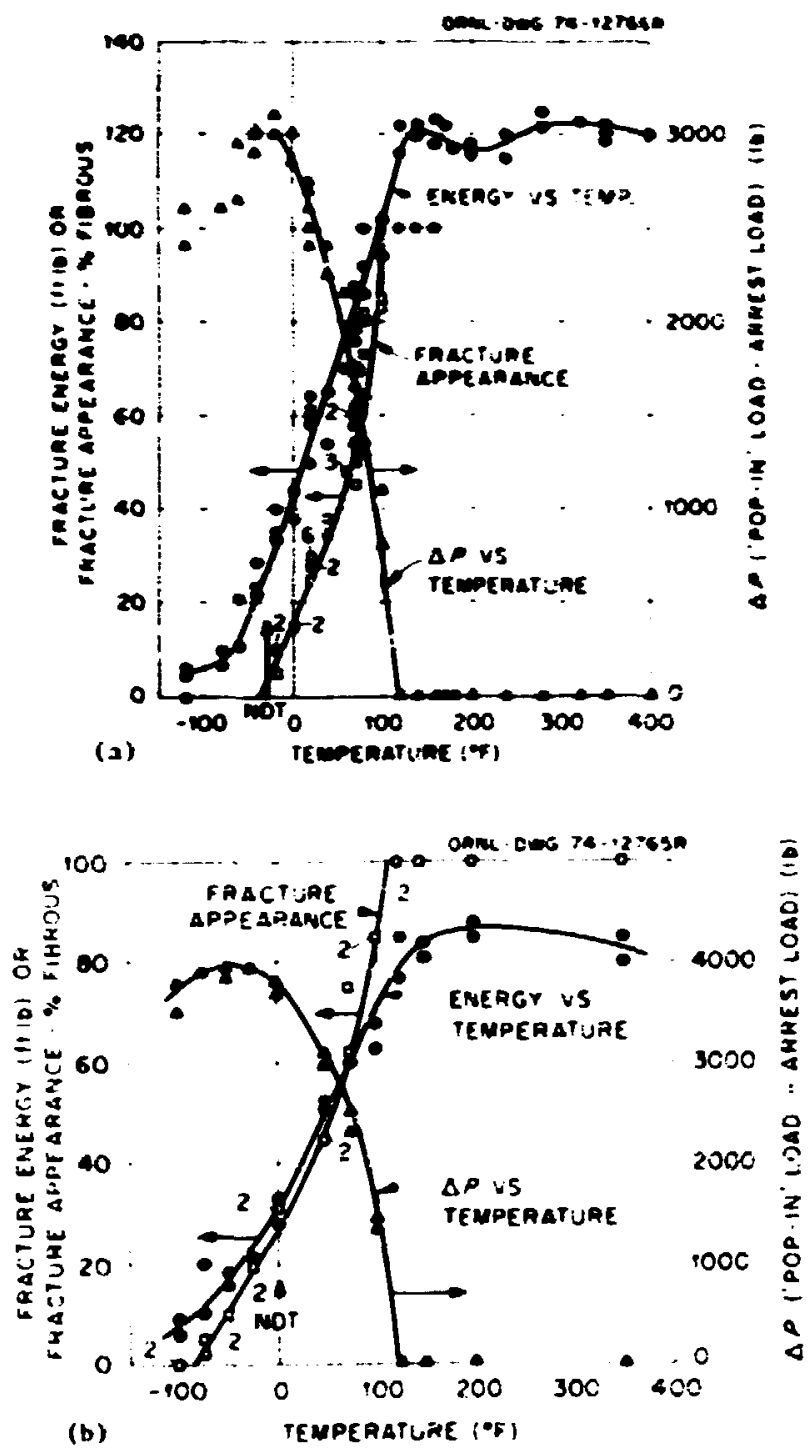

F18. 7. Comperison of "Pop-In" Load Drop with Charpy-V Impact Energy for the Low-Alloy High-Strength Steels Employed in the Fabrication of the Pressure Vessels for I.1ght--Water Reactors. The nil-ductility temperature was determined in accordance with ASTM E 208 . (a) SA-533 Grade B Class 1. (b) SA-508 Class 2.

upper-shelf energy appears to exist for the low-alloy high-strength steels employed in the fabrication of nuclear pressure vessels. The NDT was deternined by the drop-weight test for the SA-533 Grade B Class 1 and SA-508 Class 2 steels whose $C_{y}$ toughness propertiee are presented in Pig. 7. The NDT for these two steals are -25 and $0^{\circ} \mathrm{P}\left(-32\right.$ and $\left.-18^{\circ} \mathrm{C}\right)$. At NDT $+125^{\circ} \mathrm{F}\left(69^{\circ} \mathrm{C}\right)$ and $\mathrm{NDT}+150^{\circ} \mathrm{P}\left(83^{\circ} \mathrm{C}\right)$, the $\mathrm{C}_{\mathrm{v}}$ values reflect upper-shelf toughness for the SA-533 Grade B Class 1 and SA-508 Class 2 steels respectively. Specifically, to obtain upper shelf $C_{v}$ values for SA-533 
Grade B Class 1 and SA-508 class 2, cesting should be conducted at IDT + $180^{\circ} \mathrm{F}\left(100^{\circ} \mathrm{C}\right)$. This increase above NDT, whish is probably 20 to $60^{\circ} \mathrm{F}$ $\left(11-33^{\circ} \mathrm{C}\right.$ ) above the temperature at which $M P=0$, will provide an assurance that $C_{y}$ testing is being conducted on the upper shelf, and will vary from steel grade to steel grade. For example. the onset of upper shelf for the low carbon $21 / 4 \mathrm{Cr}-1$ Ho steel shown in Fig. S is about $25^{\circ} \mathrm{F}\left(14^{\circ} \mathrm{C}\right.$ ) above the NDT. Hence, while we recomend $\mathrm{MDT}+180^{\circ} \mathrm{F}\left(100^{\circ} \mathrm{C}\right)$ for the SA-508 Class 2 and SA-533 Grade Class 1 steels, we do not consider the $180^{\circ} \mathrm{F}$ temperature add-on as being a universal constant for all steels.

In view of the behavioral pattern show in Fig. 1 it may be prudent to deternine the energy values at temperatures above the onset of upper shelf. When that information is needed wr propose that the testing procedure be correlated with the operating temperaturs and/or wor. For unirradiated steels we recomaend that tests be coaducted at $\mathrm{NDT}+300^{\circ} \mathrm{F}$ $\left(167^{\circ} \mathrm{C}\right)$, at $\mathrm{NCT}+425^{\circ} \mathrm{F}\left(236^{\circ} \mathrm{C}\right)$, and at the operating teaperature of the pressure vessel. These energy data, which are obtained in addition to the energy at the onset of the $C_{v}$ upper shelf, will define the entite upper-shelf energy spectrum.

\section{conclusions}

Criteria for deternining the onset of the $C_{y}$ upper-shelf energy have been sugsested. These criteria can be applied as follows:

1. In an instrunented $C$ test, the drop in load (in the load-tine curves for the various tests) decreases with increasing temperature and is zero at the onset of the $C_{v}$ upper-shelf energy. This observation pernits the determination of the onset of the upper shelf with a minimal nubber of test specimens. Linear extrapolation of the $\Delta P$ values froa cests conducted in the transition temperature regine to zero will provide the temperature at which onset of the upper shelf is achieved.

2. In the event that an instrunented inpact cester is not available, an estimate of the temperature of the onset of the upper shelf can be based on the drop-weight NDT. For SA-S08 Class 2 and SA-533 Grade B Class 1 steels, we recomend that tests be conducted at $\mathrm{kDT}+180^{\circ} \mathrm{F}\left(100^{\circ} \mathrm{C}\right)$.

3. If the energy value is needed at a specific temperature in the upper-shelf range, then specimens must be tested at the temperature of interest.

4. To determine the variability of the upper-shelf energy for the current nuclear pressure vessel steels, we suggest that tests be conducted at

(a) $\mathrm{SDT}+180^{\circ} \mathrm{P}\left(100^{\circ} \mathrm{C}\right)($ or at the temperature at which $\triangle P=0)$

(b) $\mathrm{NDT}+300^{\circ} \mathrm{F}\left(167^{\circ} \mathrm{C}\right)$

(c) $\mathrm{NDT}+425^{\circ} \mathrm{F}\left(236^{\circ} \mathrm{C}\right)$

(d) Operating Temperature

This procedure will also provide a basis for assessing the influence of irradiation on the upper-shelf energy values.

5. The application of the drop-in-load $(\Delta P)$ criterion to deternine the unset of $C_{y}$ upper shelf is particularly useful when irradiated survelllance speclmens are tested. Usually, the nuber of spectimens is 
lintited and the definticion of the upper-sbelf temperature rane with a ainial auber of specinens is necessary. The extrapolation of the $\Delta F$ values to zero guides the selection of the test tempratures.

\section{Acopindugars}

The authors wish to thank T. H. Joses who participated in the testine proercas that provided the archive date neceseary for this correlation; U. X. Butcher for preparins the draft; Sigfred Peterson for editins; and Regina Collins for teping and preparins the report. 


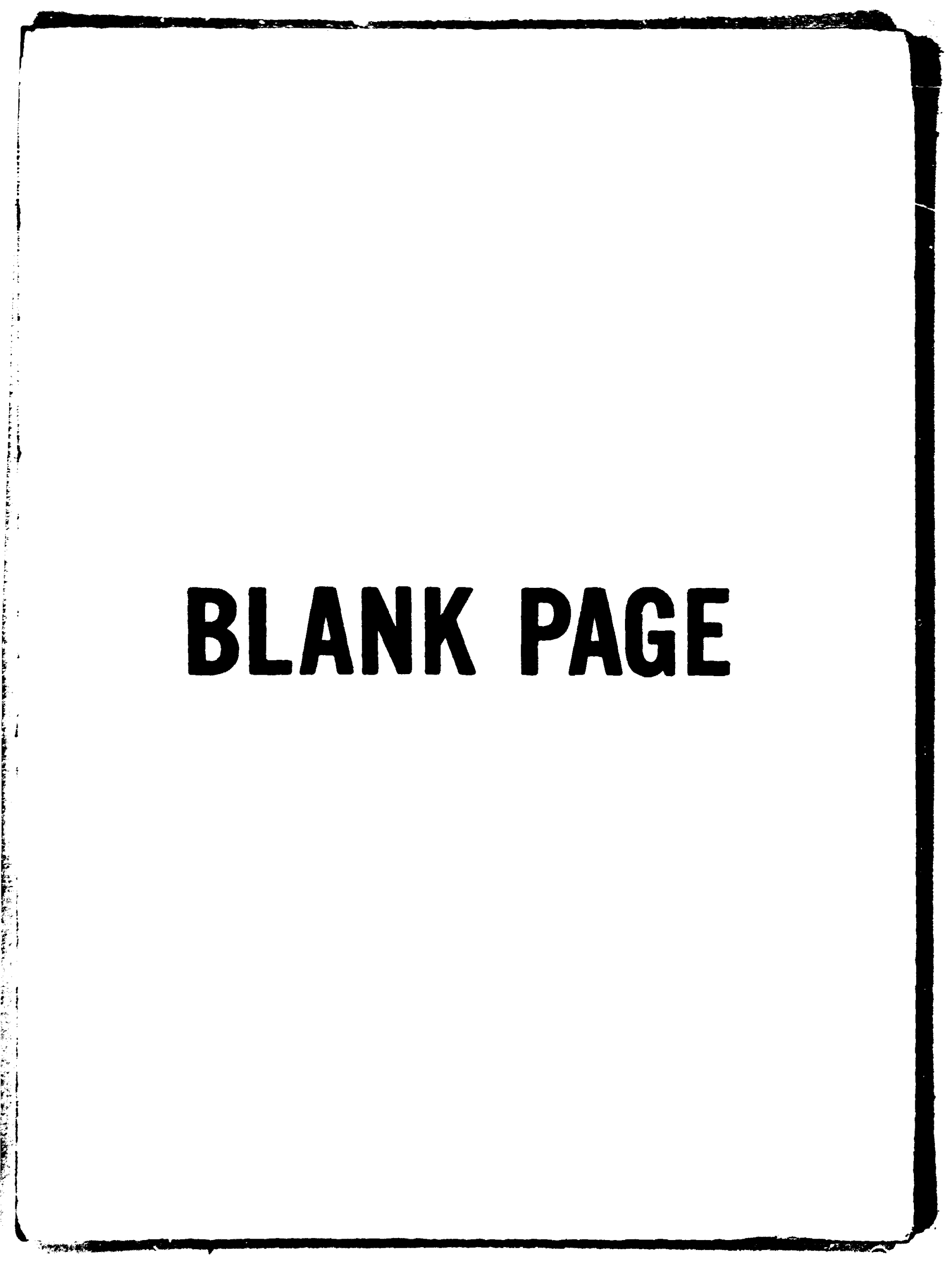




\section{ArTaDIX}

The following are sumaries of the discussions between the identified Oall personnel and the noned researcher from the organiention efted. Tre question posed to the individual mand was "lou does gour orgentastion assure itself that it has determined the upper-shelf esers valm in a Charpy V-notch rest?"

1. J. R. Barthorwe, Eaval Research Laboratory

(Discuseion with R. G. Deregren, OdL, Maj 5, 1975)

During Charpy V-notch testing Fill imvestgators ateme co firet find the temperature corresponding to the onset of $100 \mathrm{f}$ flbrow fracture as asseased by a fracture appearance criterion. They then teat at 100 to $150^{\circ} \mathrm{F}$ $\left(56-83^{\circ} \mathrm{C}\right)$ above the 1002 fibrowe fracture remperature. If affictent apec1nens are avallable they also test specinens at $550^{\circ} \mathrm{F}\left(20^{\circ} \mathrm{C}\right)$. The individual experineatal data points are reported and a viand beat fit curve Is drava throuch the points. When the $1 \mathrm{ll}$ investigators are tolalaties the "upper-shelf" enersy thes report the eaeres value an temerature at which they obtain 1002 fibrous fracture, the eneres at 100 to $150^{\circ} \mathrm{F}$ above the $100 \mathrm{t}$ fibrous temperature, and the eaersy at 550\%. They aloo indicate whether the energy curve is rising (increase in absorted emerty with an increase in test temperature) or falling (decrease in aboorbal energy with increase in test temperature) or constant with rising tenperature.

2. T. U. Marston, Combustion Engineering Company

(Discussion with R. G. Bergeren, ORn, July 21, 1975)

Combustion Engineering Company, on current contracts involving core plate materials, prepares 24 specimens each in the transverse and loagitudinal orientations. All tests are conducted in triplicate, ad tranversely oriented speciens are tested firtt. Testing sequence is as follows:

1. Text at $100^{\circ} \mathrm{F}\left(38^{\circ} \mathrm{C}\right.$ ) (triplicate specineas). This is to check on $50 \mathrm{ft}-1 \mathrm{~b}(68 \mathrm{~J}), 0.035 \mathrm{in}$. $(0.89-)$ laceral expansion requirements.

2. Test at $160^{\circ} \mathrm{F}\left(71^{\circ} \mathrm{C}\right)$. If a minim of 1002 shear fallure ad $75 \mathrm{ft}-1 \mathrm{~b}(102 \mathrm{~J})$ energy is obtained on all three spectwens the investigacors stop upper-shelf testing and report intm value. If any specimen does not weet the $100 \%$ shear, $75 \mathrm{ft}-1 \mathrm{~b}$ requirement they proceed to:

3. Test at $212^{\circ} \mathrm{F}\left(100^{\circ} \mathrm{C}\right)$. Requirement is 1002 shear and 75 ft-1b energy. If the requirement is not met, the plate is refected. (It may be re-heat-treated and retested.) They have found that they gain nothing by going above $212^{\circ} \mathrm{F}$.

4. They then proceed with tests at $-40^{\circ} \mathrm{P}\left(-40^{\circ} \mathrm{C}\right)$ and cescs to deternine RT-nDr.

5. When they have deternined RT-ROT (tranoverse) they f111 out the transition curve with any remaining apecisens and deternias the curve for longftudinal orientation material, kejed to the RT-NDT.

On present contracts they wrk from minimum spectuen results. 
3. I. Palne, Rabcok and Uilcox Conpany

(Discusesfion with D. A. Canonico, Oxh, April 29, 1975)

Babcock and Uilcox Company prepares 30 Charpy V-notch specimens in addition to those required to deternine $\mathrm{mT}$-vior. The inspectors prepare

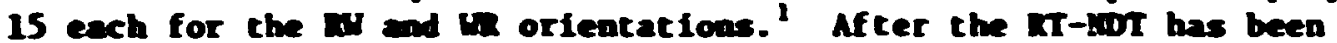
deternined they test the 15 Charpy V-notch specinens in groups of three. Their gaal is to teat two sets (of three each) at a temperature at which they obtain 952 or core fibrous fracture. Usually the two test tenperatures are $100^{\circ} \mathrm{F}\left(56^{\circ} \mathrm{C}\right)$ apart. They average the Charpy V-woteh emergies that are obtaired at each temperature, ad the upper-shelf energy is defined as the higher of the two averages. If the average of either set is belor $75 \mathrm{ft}-1 \mathrm{~b}(102 \mathrm{~J})$ they test wother set of three at a higher temperature [at least $50^{\circ} \mathrm{F}\left(28^{\circ} \mathrm{C}\right)$ higher]. The Charpy V-notch uppershelf emergy is the higher average of the two sets over $75 \mathrm{ft}-1 \mathrm{~b}$. If they do wot obtain $75 \mathrm{ft}-1 \mathrm{~b}$ that beat of steel is not acceptable for the core region.

The specimens that reanin after the toughness requirements are satisfied are used to obtain Charpy V-notch data at other temperatures.

-The first letter describes the anjor specina axis; the second letter describes the fracture propagation direction. (R signifies anor rolling dirertion, 4 signifies transverse to the anjor rollins direction.) 